\title{
A VIEW ABOUT THE IMPORTANCE OF THE LEGAL AMAZON INDIGENOUS PEOPLES ENVIRONMENTAL MANAGEMENT
}

\author{
UM OLHAR SOBRE A GESTÃO AMBIENTAL DOS POVOS INDÍGENAS NA AMAZÔNIA LEGAL \\ UNA MIRADA A LA GESTIÓN AMBIENTAL DE LOS PUEBLOS INDÍGENAS EN LA AMAZONÍA LEGAL
}

\author{
Francisco Gilson Rebouças Porto Júnior \\ Doutor em Comunicação e Cultura Contemporâneas \\ pela Faculdade de Comunicação da Universidade. \\ gilsonportouft@gmail.com
}

\section{0-0002-5335-6428}

\section{Vinicius Benites Alves}

Graduado em Ciências Biológicas, pela Universidade do Sagrado Coração (USC), Bauru/SP.

vibalves@gmail.com

0000-0002-2082-5400

\section{Isaltina Santos da Costa Oliveira}

Especialista em Psicopedagogia Educacional e Empresarial pela Faculdades Faccat, de Tupã/SP. tininhacost@gmail.com

0000-0002-5735-952X

\section{Juliene Santana da Costa}

Especialista o em Gestão em Serviço Social e Políticas Públicas pela Faculdade do Noroeste de Minas - FINOM juliene_santana@hotmail.com

\section{0-0003-3603-9911}

Mailing address: Universidade Federal do Tocantins. Quadra 109 Norte, Avenida NS 15, Plano Diretor Norte, 77001090 - Palmas, TO - Brasil

\author{
Received: 10.12.2020. \\ Accepted: 11.20.2020. \\ Published: 01.01.2021.
}

\begin{abstract}
:
The present work focused on the study, reading and reflection on the National Policy for Environmental and Territorial Management in Indigenous Lands (PNGATI) and the Territorial and Environmental Management Plans (in Portuguese, Plano de Gestão Territorial e Ambiental - 'PGTAs'), of indigenous lands of the peoples belonging to the Legal Amazon, through a documentary bibliographic research. These documents aim to bring a look at the significant contribution of indigenous peoples to the conservation of biodiversity, presenting the way of life of these peoples, the care they have with their territories for physical and cultural reproduction, as well as their challenges in face of the development model adopted by the country. The PGTAs in question refer to the Jamamadi, Yanomami and Wajãpi peoples of the respective states of Amazonas, Roraima and Amapá.

KEYWORDS Indigenous peoples; Legal Amazon; Environmental and Territorial Management; Public policy.
\end{abstract}

\section{Introduction}

Brazil is one of the richest countries in natural resources in the world, for its lush forests, its majestic rivers, its exotic fauna and, mainly, its population diversity. The Amazon rainforest with all its complexity, represented by its diverse ecosystems, is characterized by the great heterogeneity of flora and fauna, which contribute decisively to the maintenance of fundamental ecological processes (SHUBART, 1983). We find in this biome about 21,000 species of flora, an immense diversity of invertebrates, with emphasis on the 3,000 species of bees, about 2,000 species of fish, 163 species of amphibians, 550 species of reptiles, 1,000 species of birds and 311 mammals (MMA, 2002).

According to the Amazon Development Superintendence (SUDAM), the Legal Amazon is defined by a spatial and administrative cut created by the Federal Government for the purposes of planning and economic intervention. The region has an area of 


\section{revisto Observatório}

approximately 5.1 million $\mathrm{km}^{2}$ and corresponds to around $59.1 \%$ of the national territory. Amazon covers, in its totality, the states of Acre, Amapá, Amazonas, Mato Grosso, Pará, Roraima, Rondônia, Tocantins and, partially, the State of Maranhão, west of the 44th Meridian (SUDAM, 2018). It covers 771 municipalities, where just over 23 million people live in (IBGE, 2009).

Figure 1 - Legal Amazon, 2019

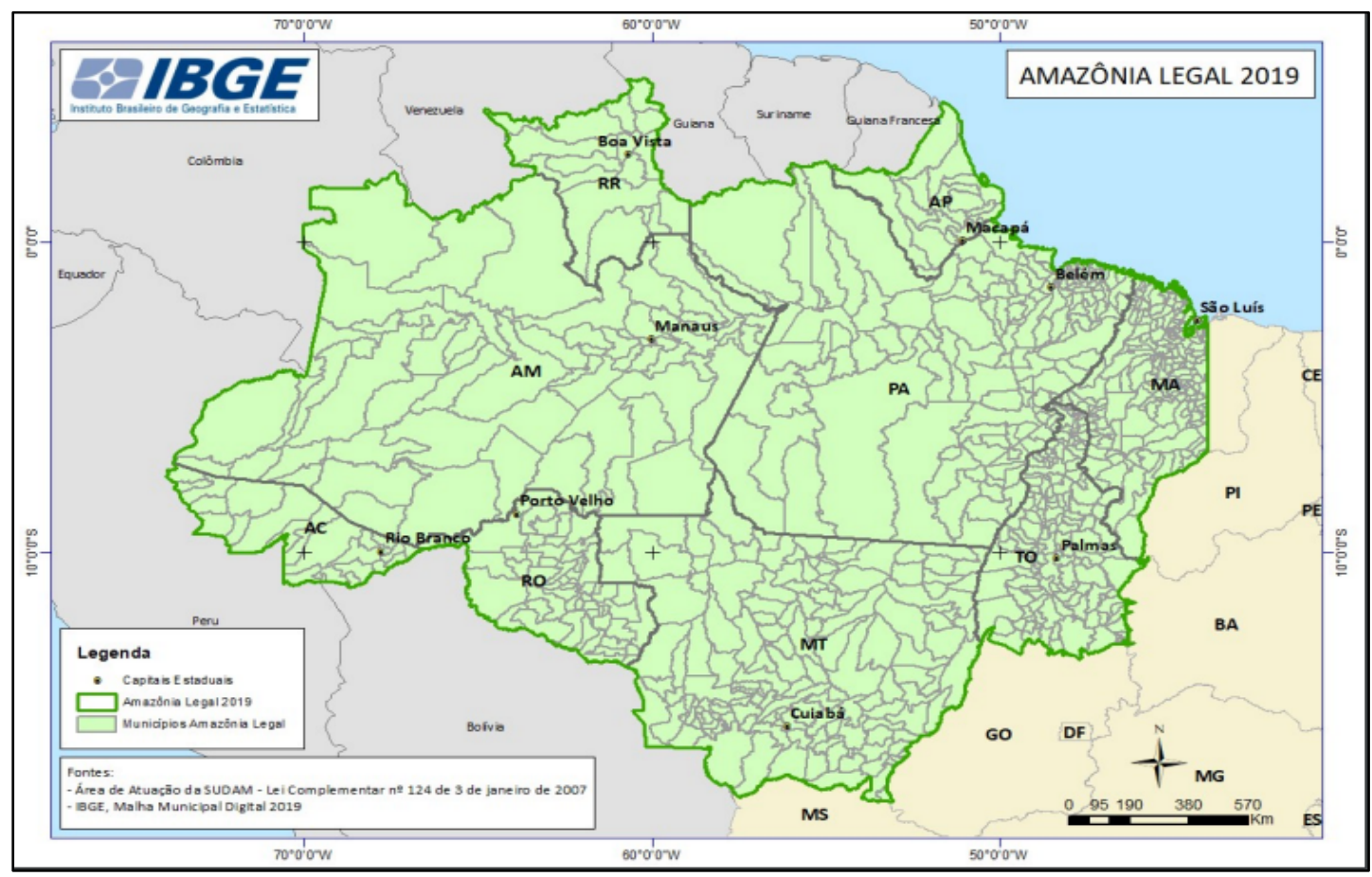

Source: https://portaldemapas.ibge.gov.br/portal.php\#mapa222992

At the same time, there are in a large part of the northern region of Brazil, and in almost all tropical forests in the world, populations with in-depth knowledge and different ways of appropriating biodiversity (SMITH \& WISHNIE, 2000). In Amazon, these local populations are the indigenous peoples, quilombolas, riverside communities, rubber tappers, babassu coconut breakers and other peasants. Many authors claim that these populations strongly contributed to the current conformation of Amazonian biodiversity and agrobiodiversity, managing the landscape for centuries, suggesting the existence of a complex interaction between cultural and biological diversity (POSEY, 1983; BALÉE, 2003).

It is known today that tropical forests and their rich biodiversity are threatened, to a greater degree, by the establishment of economic development policies that do not consider the characteristics of ecological systems (PRIMACK \& RODRIGUES, 2012). The knowledge, traditions, and forms of organization of local populations are also not 
considered in the processes of economic development and in social and environmental projects, in which public policies are generally top-down placed.

Several studies demonstrate the effectiveness of indigenous lands in resisting the pressure of deforestation in Brazil. Nolte et al. (2013), compared the capacity of areas protected by the government, sustainable use areas and indigenous community forests to resist deforestation and concluded that indigenous lands "were considered consistently facing the highest levels of deforestation pressure and reaching the highest level of avoided deforestation". Similarly, Nepstad et al. (2006) concluded that indigenous lands "strongly inhibited deforestation on the active agricultural frontier" (WRI, 2014).

Brazil has a territorial extension of $851,196,500$ hectares, that is, $8,511,965 \mathrm{~km} 2$. Indigenous lands (ILs) total 724 areas, occupying a total area of $117,377,553$ hectares $(1,173,776 \mathrm{~km} 2)$. Thus, $13.8 \%$ of the country's land is reserved for indigenous peoples. Most ILs are concentrated in the Legal Amazon: there are 424 areas, 115,344,445 hectares, representing $23 \%$ of the Amazonian territory and $98.25 \%$ of the extension of all ILs in the country. The remainder, $1.75 \%$, is spread over the Northeast, Southeast, South and states of Mato Grosso do Sul and Goiás (INSTITUTO SOCIOAMBIENTAL, 2019).

Although many areas in the South and Southeast of Amazonas are demarcated, representing a considerable extent of conserved natural environments, the interface region between the states of Acre, Rondônia and Amazonas is a scenario of expansion of the agricultural frontier, which has been attracting more robust incentives to increase local infrastructure, notably through energy generation constructions, and recovery and paving of the BR-364, BR-319 and BR-230 highways, used and considered vectors of the deforestation process. It is in these regions that the impact of occupation in the hydrographic basinis concentrated, mainly associated with the activities of timbering, agriculture, illegal mining, and fishing.

These movements cause expropriation of public lands by private speculators, illegal logging, deforestation and forest fires, the expulsion of traditional populations and pressure on indigenous lands. This process has been called the Rondonization of the South and Southeast of Amazonas. This dynamic is reflected in deforestation studies and projections for the region, which indicate risks not only to the enormous cultural diversity, but also threaten the forests of that region, as well as their great biological diversity, rich in endemic species of extreme relevance for conservation.

The fight for the demarcation of Indigenous Lands began in the 1970s, and in the 1980s the indigenous movement began to gain strength, where the first indigenous associations were formed. In this period, the indigenous movement improves its 
articulation and manages to participate and guarantee its rights in the Federal Constitution of 1988 (articles 231 and 232). In 1992, the United Nations (UN) held ECO 92, which had as its main focus the concern with environmental problems, highlighting the urgent need for behavioral change in order not to further aggravate the degradation of the environment.

After this moment, there was a closer relationship between the indigenous movement and the environmental movement, which strengthened the fight for social and environmental actions in Brazil and in the world. With this gain in visibility, in 1996 the Integrated Project for the Protection of Indigenous Populations and Lands in the Legal Amazon (PPTAL) began, which was the result of an agreement between the governments of Brazil and Germany. PPTAL received funds donated by the German Development Bank (KfW) and had the support of the German Technical Cooperation Agency (GTZ) and the National Indian Foundation (FUNAI). The PPTAL was carried out for 13 years (1996 to 2008) and contributed to recognize 107 million hectares as an indigenous area in Brazil, $98 \%$ are in the Legal Amazon.

\begin{abstract}
Among the established goals, the PPTAL accomplished 92\% of the proposed objective for the identification of Indigenous Lands, making a total of 12 million hectares, distributed in 77 identified territories. In the demarcation process, the Project secured 39 million hectares in 106 Indigenous Lands in the Legal Amazon. In addition to land tenure regularization, the PPTAL carried out 44 projects for the Protection and Surveillance of Indigenous Lands, 22 studies for the elaboration and review of Funai technical standards, 132 indigenous training actions, 7 radio projects and developed a methodology for ethno-ecological surveys, of which 8 have already been completed (FUNAl, 2009).
\end{abstract}

The theme of territorial management in Brazilian indigenous lands is a current agenda for indigenous peoples. After some peoples have overcome the challenge of demarcating their lands, they now have new challenges that are related to environmental management and territorial protection.

On June 5, 2012, through Decree No. 7,747, the National Policy for Territorial and Environmental Management of Indigenous Lands (PNGATI) was instituted. According to art. 1, PNGATI's general objective is to guarantee and promote the protection, recovery, conservation and sustainable use of the natural resources of indigenous lands and territories, ensuring the integrity of the indigenous heritage, improving the quality of life and full living conditions for physical and cultural reproduction of current and future generations of indigenous peoples, respecting their socio-cultural autonomy.

Unlike the indigenous laws of the pre-Federal Constitution of 1988, PNGATI starts from democratic assumptions such as the right to consultation, thus allowing prominence 
through a participatory governance methodology that recognizes the representative social and political organizations of indigenous peoples, with the objective of promoting the territorial and environmental protection of ILs. Each people exercise its relationship with the environment, according to its culture. So, here is the relationship with the cultural conception of territory. From symbolic territory, lived territory, different from the political and controlling territory of the State.

This policy provides, through participatory and integrated strategies, an articulation with indigenous peoples, discussing issues related to their interests, thus occurring autonomy regarding the sustainable development of these communities.

One of the ways to meet the implementation of this policy is through support for the territorial and environmental protection of indigenous lands through surveillance and monitoring, strategically valuing the role of indigenous people in the sustainable use of natural resources and guaranteeing food sovereignty, as well as the engagement of young people for the future of the territories. Currently, this is one of the priority policies in progress for indigenous territories, which requires, in addition to field actions, the involvement of various social actors in direct articulation with the Ministry of Justice and the Ministry of the Environment.

The main actions seek to: a) recognize and value the social and political organizations of indigenous peoples; b) promote the role and socio-cultural autonomy of indigenous peoples, specially by strengthening their organizations, ensuring indigenous participation in PNGATI governance, respecting indigenous representation bodies and the gender and generational perspectives; c) environmentally protect the territory, improving the quality of life in areas reserved for indigenous peoples and on indigenous lands; d) guarantee the development of environmental management as an instrument for the protection of territories and the environmental conditions necessary for physical and cultural reproduction and the well-being of indigenous peoples and communities.

For the National Policy on Environmental Management of Indigenous Lands (PNGATI), PGTAs are considered to be implementation instruments and in recent years, indigenous peoples and indigenous organizations have developed different methodologies for the development of these tools.

\section{Development}

Since the creation of PNGATI, this public policy has become an efficient and continued instrument in the sense of recognizing and strengthening this effective contribution of indigenous peoples in the conservation of biodiversity, through traditional and community management of natural resources. At the same time, it is an instrument 
that seeks to promote the articulated and integrated performance of government institutions and civil society, overcoming demonstrative, punctual and sometimes isolated actions regarding the promotion of environmental and territorial management of indigenous lands.

According to Bavaresco and Menezes (2014, p. 9):

\begin{abstract}
PNGATI was built with the participation of indigenous peoples and comes to recognize and support the environmental and territorial management that is already carried out by these peoples in their lands. This public policy creates space and brings opportunities for indigenous peoples and the State to dialogue around a common objective and combine their forces to face the difficulties and challenges that Brazilian indigenous peoples face today. Access to knowledge is an important aspect in the fight for citizenship and the role of this publication is to offer potential implementers of PNGATI the possibility of understanding this public policy, with the objective of putting it into practice in their daily activities. The more knowledge one has about one's environment, one's rights and one's role in society, the greater the citizen's fighting power for respect for these rights and the more convinced one will be of the need to fulfill one's duties. Putting PNGATI into practice requires a new way of acting for indigenous and non-indigenous managers. In this new context, it is essential that they can find clear and objective information, opportunities for dialogue, reflection, construction and joint proposition of actions, aiming to qualify and enhance the performance of managers in their regions.
\end{abstract}

PNGATI article 2 defines that ethno-mapping and ethno-zoning are tools for territorial and environmental management of indigenous lands. Single paragraph. For the purposes of this Decree, the following are considered:

I - Ethno-mapping: participatory mapping of areas of environmental, socio-cultural, and productive relevance for indigenous peoples, based on indigenous knowledge and expertise; and

II - Ethno-zoning: participatory planning instrument that aims to categorize areas of environmental, socio-cultural, and productive relevance for indigenous peoples, developed from ethno-mapping.

Ethno-mapping (or participatory mapping) uses the spatial and environmental expertise of local populations, their interests, views and understanding of the territory, this being a powerful tool for territorial planning. It translates into the construction of a map with the relevant places, its cultural use, the spatial distribution of natural resources, the identification of environmental impacts among various other relevant information for the people.

At first, a mind map is collectively built to guide the next steps of the mapping, serving as the primary base of data to be georeferenced. Through workshops, the 
situation of biodiversity used by communities is assessed, and a discussion is held on the sustainable management of these resources. This discussion will be based on the information raised in the ethno-mapping, but the communities are provoked to think about other resources not mapped until this stage. Ethno-zoning is an indigenous planning and planning tool based on its categories of classification and use of the territory, considering the priorities of each people.

Priority resources are also defined so that more detailed management programs / plans can be considered. After this survey, ethno-zoning work and the discussion about collective agreements are developed, which result in the elaboration of the Territorial and Environmental Management Plan (PGTA).

The PGTA discusses and reflects the entire management of the territories, establishing agreements on transversal and more important themes such as: education, health, territorial surveillance, management of biodiversity, agricultural production, cultural strengthening, and other development projects.

According to preliminary data from Funai and TNC, as shown in the table below, it is estimated that the number of indigenous lands that have PGTA or some other planning instrument for the implementation of PNGATI is still low.

Table 01: Number and Area of Indigenous Territorial Planning Instruments in the Legal Amazon (2019)

\begin{tabular}{|l|c|}
\hline Planning tools for the implementation of PNGATI & No of indigenous lands \\
\hline PGTA & 111 \\
\hline Ethno-mapping or Ethnozoning & 39 \\
\hline Life Plans & 13 \\
\hline Others & 19 \\
\hline Without instrument & 203 \\
\hline Total & $\mathbf{3 8 5}$ \\
\hline
\end{tabular}

Source: FUNAI and TNC complements - preliminary results.

\section{Presentation of indigenous peoples}

The Jamamadi

The Jamamadi people inhabit the Indigenous Land (IL) Jarawara / Jamamadi / Kanamanti, located to the left shore of the Purus River. They are speakers of the Jamamadi language, of the Arawá linguistic branch. Its current population is just over 380 people. They are known in the region for their beautiful handicrafts, such as basket weaving. They make their houses out of woven roofs made of ubim and caranaí straw. They love to hunt, 
to take copaiba oil without killing the tree, to make big plantation fields and they like snuff, one of the symbols of their culture.

The Jarawara / Jamamadi / Kanamanti Indigenous Land, inhabited by the Jamamadi and Jarawara peoples, is $50 \mathrm{~km}$ from the city of Lábrea (AM). This TI is inserted in a mosaic of protected areas, making borders with the indigenous lands Hi-Merimã (isolated people), Banawá and the Extractive Reserve Medium Purus, inhabited by riverside dwellers.

Its people are formed by several groups (Boti, Wayafi, Hi-Merimã, Madi, Hawa and Kosiba), who lived in the region between the Purus and the Juruá rivers. With contact with non-Indians, diseases and exploitation by the colonization system arrived, which almost caused the extinction of some groups. To try to survive and escape from the bosses, these people left their huts, going down the river, always avoiding living on the shores of the rivers. They built their houses on dry land. Today, they have seven permanent villages and four villages that do not have a fixed place within Jamamadi territory.

The relationship with the Jarawara people, who share the same land, is somewhat conflicted and carries a history of fights and strong conflicts on both sides, a matter that is avoided by the Jamamadi, however, when they need to make external articulations, this situation loses evidence due to kinship, since the two peoples descend from the same group.

There is a well-defined division on both sides. Each people have their territory of occupation, with old villages, cemeteries and capoeiras. The social relationship between them is not constant, especially after the end of the single marriage between the ethnic groups. Despite speaking similar languages and communicating with ease, their meetings in the villages are rare, usually taking place at some xingané parties, football games or in the city of Lábrea. The relationship with the Banawá people is more friendly, according to Badá Jamamadi, one of the people who contacted them. The dialogue is facilitated by the similarity between languages. There is an intense participation of several Jamamadi in parties in the Banawá villages, which are also used as places of support at the time of the extraction of copaiba and chestnut oil.

\section{The Yanomami}

The Yanomami call the place where they live as Urihi A, which can be translated as our forest land. Urihi $A$ is also known as Yanomami Indigenous Land (TIY) and was approved by the Brazilian government in 1992, with an extension of 9,664,975 hectares and it is located between the municipalities of Barcelos, Santa Isabel do Rio Negro, São 
Gabriel da Cachoeira, Alto Alegre, Mucajaí, Caracaraí, Iracema, in the states of Roraima and Amazonas, on the border between Brazil and Venezuela.

They live with the Ye'kwana people and with several groups that are still out of contact, such as Isolates from Serra da Structure, Isolates from Amajari, Isolates from Auaris / Fronteira, Isolates from the Lower Rio Cauaburi, Isolates Parawa u, Isolates Surucucu / Kataroa. They are speakers of the Yanomani language and have about 26 thousand inhabitants, living in more than 330 communities, part of them of the Ye'kwana people,

The Ye'kwana represent 3\% of the total population and know IL Yanomami as Tönoonoi, which, in their language, means "place where we have lived since our inception". Their land is in eight municipalities between the states of Roraima and Amazonas, on the border between Brazil and Venezuela and there are many mountains, plains and rivers. It is the largest Indigenous Land in Brazil and it forms one of the most important areas of continuous forest in the country, with very few deforested or degraded areas, because the Yanomami and Ye'kwana have always been there, taking care of it.

Between 1986 and 1990, 40,000 prospectors invaded the forest land. Because of the diseases brought by the prospectors, the Yanomami lost 20\% of their population and in 1993 they suffered a violent massacre, the Haximu Massacre, which became known worldwide.

Yanomami communities have collective spaces, in which decisions are made by the group of older men. These decisions are discussed with the whole family and the community and in meetings they call hereamu. The Ye'kwana do it differently: the elders, who are usually the heads of extended families, form a circle of elders who are always consulted for collective decisions.

Their local governance is this way: neither the Ye'kwana nor the Yanomami have a head leader who decides everything on his own. Everyone participates and decides together the paths, under the guidance of the oldest and most experienced. They have their own ways of making decisions, which non-indigenous people often call governance. At Yanomami IL there are two different peoples, and each have their own way of deciding on matters that are important to their lives.

\section{The Wajãpi}

The Wajãpi people are located between the municipalities of Pedra Branca do Amapari and Laranjal do Jari in the state of Amapá and on the border with French Guiana. Their land was approved in 1996, with an extension of 607,000 hectares, and its surroundings are formed by the Tumucumaque Mountains National Park, the Iratapuru 
River Sustainable Development Reserve, the Amapá State Forest, the Beija-Flor Brilho de Fogo Extractive Reserve and the Perimetral Norte Settlement Project, which are part of the mosaic of protected areas in Eastern Amazon.

They are speakers of the Tupi Guarani trunk and currently, their population is about 1,200 people distributed in more than 90 villages. Its social organization is complex, as it does not have a single head, but several groups called iwanã kõ, and each group has its heads. They have heads of villages and heads of families.

At the time of the demarcation, they were organized through the Wajãpi Village Council - Apina, which is a council of chiefs, helped by all Wajãpi. This is how they make decisions that affect all groups: they meet in the Council and everyone decides together how they will act. Since demarcation, this is how they organize themselves to strengthen their way of living. Currently, they have organizations beyond Apina: the Wajãpi Land, Environment and Culture Association (Awatac), which helps the Council to execute its decisions,

Since they demarcated their land, they strive to occupy their limits, carrying out territorial surveillance. Its land is crossed by the Perimetral North Road, the BR-210, which comes from Macapá, passes through Pedra Branca do Amapari and crosses the Perimetral North Settlement. They have several villages on the side of the road, but they also have many villages far from it, which are only accessible by boat, on foot or by air as a territorial protection strategy.

As for the preparation of the PGTAs of the respective peoples, the Jamamadi Territorial Management Plan: Jamamadi People Jarawara / Jamamadi / Kanamanti Indigenous Land - "Who knows what is good for Jamamadi is Jamamadi", had the partnership of Native Amazon Operation (OPAN). The Territorial and Environmental Management Plan Yanomami Indigenous Land - with consultation protocol Yanomami and Ye'kwana, had a partnership with the Socio-Environmental Institute (ISA) and the Socio-environmental Management Plan Terra Indígena Wajãpi - How we are organized to continue living well in our land, had a partnership with the Institute for Research and Indigenous Training (IEPÉ).

About the PGTA of the Jamamadi, it is bilingual and is structured in: Presentation; Jamamadi People's Organization; Young-Girl Party; Jarawara / Jamamadi / Kanamanti IL; Indigenous Lands and Conservation Units; Jamamadi people and the neighbors of their land; Missionary Action with the Jamamadi; For Jamamadi, the Management Plan is: Plantation field; Flour; Snuff; Hunting; Fishing; Copaiba; Andiroba; Brazil nuts; Fruit Collection; Vine; Crafts; Games; Education; Health; Beverage; Garbage; Surveillance; Federal Constitution and PNGATI - Decree No. 7,747, of June 5, 2012. 
The Jamamadi, with support from OPAN, started to elaborate the Territorial and Environmental Management Plan (PGTA) to face the current challenges. The management plan shows the Jamamadi culture in which they learn everything from parents and grandparents and teach their children their way of life, in addition to showing how Jamamadi thinks about taking care of their land, how they will improve their land, how they will take care of Jamamadi culture.

\begin{abstract}
We want our children to continue living the way the Jamamadi have always lived in the future. Learning to farm, to hunt, to fish, to collect fruits, to make handicrafts, to make houses. In the same way that we learn from our parents, we want to teach our children and we want them to live the same way (TERRITORIAL MANAGEMENT PLAN JAMAMADI, 2015, p. 32).
\end{abstract}

In the Jamamadi organization, there is representation through chiefs and other leaders as a teacher, AIS (Agents of Indigenous Health), pilots, pastors and, when there is a common cause, everyone unites and joins forces to defend their people. The PGTA of the Yanomami Indigenous Land is bilingual and is structured in: Presentation; The Yanomami Indigenous Land; What is PGTA?; Why did we write this Plan ?; How was this document made? The seven themes: 1 - Our way of making decisions; 2 - Our way of protecting the land; 3 - Our way of generating income and dealing with money; 4 - Our knowledge; 5 - Our way of taking care of the forest; 6 - Our health; 7 - Our way of educating; Glossary; Consultation Protocol and Consultation Guide.

It is a document made to record ideas regarding what is necessary so that all Yanomami and Ye'kwana peoples can live well, in the present and in the future, with the intention of showing the government and non-indigenous people their way of caring for the Yanomami Indigenous Land. The PGTA was also designed to listen to the sages on how to defend the Yanomami Indigenous Land and transmit traditional knowledge to young people.

The PGTA is to keep all of us Yanomami and Ye'kwana living well in our land. Non-indigenous people give this name PGTA to what we call Urihi, our forest land. [...] This PGTA is to keep all of us standing, as the forest holds the Earth tightly. The essential image of our forest land defends all of us Yanomami and Yek'wana. The PGTA is for us as an identity document of our forest land, as it brings with it its essential image (TERRITORIAL AND ENVIRONMENTAL MANAGEMENT PLAN INDIGENOUS TERRA YANOMAMI, 2018, p. 84).

And the Wãjapi PGTA, also bilingual, is structured in: Introduction; Who we are; Why we made this Social and Environmental Management Plan; Our ways of living: Our 
knowledge of environments and owners; Our territorial mobility; Our ways of making decisions; Problems we face and our agreements to solve them: How we analyze the problems; plantation field and fruit trees; Hunting and fishing; Materials for making houses and utensils; Garbage; Everyone's participation in territorial management; Occupation of the surroundings of the Wajãpi Indigenous Land; How we want government agencies to contribute: In the areas of education and health; In territorial and environmental management; How we will monitor our Management Plan: objectives and indicators and How this Plan was made.

They made this document, to value the way of life, to occupy the land, to change villages, to have parties, weddings, to raise the children, to paint the body, in short, the way of living the culture. The Plan is a new way of organizing their work to strengthen practices, based on old knowledge.

This Management Plan will be fulfilled and monitored by ourselves, Wajãpi. It serves to help us live according to our ways, but also to be able to use the land in a planned way, because our population is increasing and we have more and more contact with non-Indians. This is very important for us, and will serve forever, for the next generations (SOCIO-ENVIRONMENTAL MANAGEMENT PLAN TERRA INDÍGENA WAJÃPI, 2017, p. 13).

\section{Final considerations}

One of the foundations of PNGATI is the recognition of territorial and environmental management instruments, which have provided basis for intercultural dialogue for the elaboration of another very important instrument for the management of indigenous lands, the Territorial and Environmental Management Plan for Indigenous Lands (PGTA). The instruments of territorial and environmental management of indigenous lands are the result of a set of experiences carried out by different actors with different methodologies, times and approaches and seeking dialogue on the management of indigenous lands.

As previously discussed, PNGATI aims to promote the sustainable quality of life of indigenous peoples in their lands, in order to respect socio-cultural autonomy and their own forms of territoriality. It is an idealized policy with legitimacy and active participation by the indigenous movement, which, in itself, already represents a reason for investments in its implementation. It deals with the need for protection and support for the sustainable development of indigenous peoples in their territories and constitutes a legal framework for the protection and promotion of indigenous rights today in alignment with the Constitution. 
In this sense, the instruments of territorial and environmental management of Indigenous Lands have been increasingly recognized as a way of supporting sustainable use, reinforcing that Indigenous Lands have a strategic role in the conservation of biodiversity and in the maintenance of ecosystem functions.

PGTAs make it possible to negotiate both internal and external agreements, building channels of dialogue with the State and with civil society organizations, creating articulations and institutional arrangements that contribute to the process of ethnodevelopment and sustainability of peoples and Indigenous Lands (TERRITORIAL MANAGEMENT PLAN AND ENVIRONMENTAL OF INDIGENOUS LANDS: GUIDELINES FOR ELABORATION, 2013).

Bearing in mind that indigenous prominence is increasingly projected into the future, PNGATI had the involvement of indigenous leaders, enabling the participation of indigenous peoples in matters that concern their interests. The PGTAs of the Jamamadi, Yanomami and Wajãpi peoples had partnerships with different indigenous organizations.

It should be noted that indigenous peoples have the right to free, prior and informed consultation, provided byart. 6 of ILO Convention 169 (International Labor Organization), autonomy, indigenous prominence and the methodology of the different levels of participation and a striking example of consultation associated with an Administrative Measure, was the construction of the National Policy for Environmental and Territorial Management in Indigenous Lands (PNGATI). The Consultation process started in 2008 with a broad mobilization that ended up involving approximately 1,250 indigenous people and resulted in the construction of PNGATI, edited by Presidential Decree No. 7,747 in 2012.

Convention 169 is an international agreement signed by several countries, including Brazil, and it concerns the rights of indigenous and tribal peoples. This treaty was approved in 1989 and became law in Brazil in 2004, with the edition of Decree $n^{\circ} 5.051$. This law recognizes that indigenous and tribal peoples have their own ways of living and organizing themselves. For this reason, the Convention protects the right to land, education, health, and participation in a different way for indigenous peoples. In addition, it establishes that indigenous and tribal peoples have the right to be consulted on any and all administrative or legislative decisions that affect collective rights and ways of life, including on their lands.

For the International Labor Organization (ILO), the basic principles of Convention 169 are: Self-identification; Non-discrimination; Special measures; Cultural specificities; Consultation and participation; Decision on priorities for its development. In addition to the right to land, the Convention deals with the rights of tribal indigenous peoples to be 
consulted whenever an Administrative or Legislative decision may affect peoples and communities or their lands.

It is understood that, in theory, PGTAs should be prepared by the indigenous people themselves, built according to the political, social, cultural and economic characteristics of each people, as well as to the environmental specificities of their territories, presupposing, therefore, indigenous prominence. In this sense, the PGTAs addressed were built respecting the constitutional precepts of autonomy and collective well-being, empowering, within the limits of public policy, the indigenous peoples in question, based on principles based on prominence, legality, sustainability, establishment of agreements and pacts.

In this document, we aimed to bring a look at the significant contribution of indigenous peoples to the conservation of biodiversity and their challenges in the face of "progress". Although there are advances in the establishment of planning instruments and in the construction of Management Plans, much remains to be done. The biggest challenges are a greater spread of PNGATI to other indigenous peoples besides the Legal Amazon, to public servants and managers.

In public policies, there is generally a low participation of indigenous peoples, so they need to be better disseminated among these communities and public bodies, in order to promote and guarantee greater involvement of these peoples. Such dissemination and strengthening of the importance of this policy are necessary so that greater support for its implementation in indigenous lands can occur, with a view to improving the management of natural resources, ensuring a better quality of life for indigenous populations and future generations, since PGTAs have the potential to contribute to enhancing the knowledge of indigenous peoples about their territories.

\section{References}

BALÉE, William. 2003. Diversidade amazônica e a escala humana do tempo.

Florianópolis: Anais do I Simpósio de Etnobiologia e Etnoecologia da Região Sul, p. 14-28.

BAVARESCO, Andréia; MENEZES, Marcela. Entendendo a PNGATI: Política Nacional de Gestão Territorial e Ambiental Indígenas. Brasília/DF: GIZ/Projeto TI/Funai, 2014. BLASER, Ana; et al. Plano de Gestão Socioambiental - Terra Indígena Wajãpi - Como estamos organizados para continuar vivendo bem na nossa terra. Conselho das Aldeias Wajãpi - Apina, Associação Wajãpi Terra, Ambiente e Cultura - Awatac, Instituto de Pesquisa e Formação Indígena. 2017 - 100 p. 
BRASIL. Decreto n. 7.747, de 5 de junho de 2012. Institui a Política Nacional de Gestão

Territorial e Ambiental de Terras Indígenas - PNGATI. Disponível em: http://www.planalto.gov.br/ccivil_03/_Ato20112014/2012/Decreto/D7747.htm\#art 15. Acesso em: 10 out. 2020.

CORREIA, Cloude de Souza. Etnozoneamento, etnomapeamento e diagnóstico etnoambiental: representações cartográficas e gestão territorial em terras indígenas no estado do Acre. Programa de Pós-Graduação em Antropologia Social - PPGAS; Departamento de Antropologia - DAN; Instituto de Ciências Sociais -ICS; Universidade de Brasília - UnB; Brasília/DF, 2007, 431 p.

FUNAI. Fundação Nacional do Índio. Plano de Gestão Territorial e Ambiental de Terras Indígenas: Orientações para Elaboração. Brasília: FUNAl, 2013. 20 p.

FUNAI. Fundação Nacional do Índio. Projeto de gestão sustentável em terras indígenas terá apoio do Governo alemão, 2011. Disponível em: http://www.funai.gov.br/index.php/comunicacao/noticias/1990-projeto-degestao-sustentavel-em-terras-indigenas-tera-apoio-do-governo-alemao. Acesso em: 30 nov. 2020.

IBGE. Instituto Brasileiro de Geografia e Estatística. Amazônia Legal 2019. Disponível em: https://portaldemapas.ibge.gov.br/portal.php\#mapa222992. Acesso em: 30 de nov. 2020.

ISA. Instituto Socioambiental. Localização e extensão das Tls. Socioambiental, 2019. Disponível em: https://pib.socioambiental.org/pt/Localiza\%C3\%A7\%C3\%A3o_e_extens\%C3\%A3o_ das_Tls\#: :text=O\%20Brasil\%20tem\%20uma\%20extens\%C3\%A3o,s\%C3\%A3०\%20 reservados\%20aos\%20povos\%20ind\%C3\%ADgenas. Acesso em: 30 nov. 2020.

MMA. Ministério do Meio Ambiente. Biodiversidade brasileira: avaliação e identificação de áreas e ações prioritárias para conservação, utilização sustentável e repartição de benefícios da biodiversidade nos biomas brasileiros. Brasília: MMA/SBF, 2002.

MONTANARI Isaias Junior. Impacto do PPTAL na Demarcação de Terras Indígenas na Amazônia Legal. Textos\&Debates, Boa Vista, n.22, p. 119-143, jul./dez. 2012.

NEPSTAD, Daniel Curtis et al. 2006. "Inhibition of Amazon Deforestation and Fire by Parks and Indigenous Lands". Conservation Biology 20(1): 65-73.

NOLTE, Christoph et al. "Governance regime and location influence avoided deforestation duccess of protected areas in the Brazilian Amazon". Proceedings of the National Academy of Sciences. doi: 10.1073/pnas.1214786110, 2013.

POSEY, Darrell Addison. 1983. Indigenous knowledge and development: an ideological bridge to future. Ciência e Cultura 35 (7): 977-994. 
PRIMACK, Richard B. \& RODRIGUES, Efraim. Biologia da Conservação. Londrina: E. Rodrigues, 2012.

SANTOS, Magno Lima; ALVES, Vinicius. Benites. Plano de Gestão Territorial Jamamadi: Povo Jamamadi Terra Indígena Jarawara/Jamamadi/Kanamanti. Operação Amazônia Nativa. Brasil, 2015. 156 p.

SHUBART, Herbert Otto Roger, 1983. Ecologia e utilização das florestas. In. Amazônia: desenvolvimento, interação e ecologia. São Paulo: Brasiliense; Brasília: CNPQ, 1983.

SILVA, Marciano Toledo et al. Nossos conhecimentos sobre a sociobiodiversidade: salvaguardando uma herança ancestral. Uma visão popular da Lei 13.123/2015, o marco legal da biodiversidade brasileira e do acesso e repartição de benefícios sobre o conhecimento tradicional associado GT Biodiversidade da Articulação Nacional de Agroecologia e Terra de Direitos, 2020, 64 p.

SMITH, Eric Alden \& WISHNIE, Mark. Conservation and subsistence in small scale societes. Annual Review of Anthropology 29: 493-524, 2000.

SOUSA, Cássio Noronha Inglez; ALMEIDA, Fábio Vaz Ribeiro (Orgs). Gestão territorial em terras indígenas no Brasil. Brasília/DF: Coleção Educação para Todos: V. 39 - Série Vias dos Saberes: № 6. Ministério da Educação, Secretaria de Educação Continuada, Alfabetização, Diversidade e Inclusão; Unesco, 2012, 268 p.

VIEIRA, Marina A. R. de Mattos; LIMA, Lucas P. das N. S. Plano de Gestão Territorial e Ambiental Terra Indígena Yanomami com Protocolo de Consulta Yanomami e Ye'kwana. Hutukara Associação Yanomami, Instituto Socioambiental, Boa Vista/RR. 164 p. 


\section{Qrevisto Observatório}

\section{RESUMO:}

O presente trabalho teve como foco de estudo, a leitura e reflexão sobre a Política Nacional de Gestão Ambiental e Territorial em Terras Indígenas (PNGATI) e os Planos de Gestão Territorial e Ambiental (PGTAs) de terras indígenas dos povos pertencentes à Amazônia Legal, a partir de levantamento bibliográfico documental. Esses documentos objetivam trazer um olhar sobre a contribuição significativa dos povos indígenas para a conservação da biodiversidade, apresentando o modo de vida desses povos, o cuidado que possuem com seus territórios para reprodução física e cultural, bem como seus desafios frente ao modelo de desenvolvimento adotado pelo país. Os PGTAs em questão, se referem aos povos Jamamadi, Yanomami e Wajãpi, dos respectivos estados Amazonas, Roraima e Amapá.

PALAVRAS-CHAVE: Povos indígenas; Amazônia Legal; Gestão Ambiental e Territorial; Políticas Públicas.

\section{RESUMEN:}

El presente trabajo se centró en el estudio, lectura y reflexión sobre la Política Nacional de Gestión Ambiental y Territorial en Tierras Indígenas (PNGATI) y los Planes de Manejo Territorial y Ambiental (PGTA) de las tierras indígenas de los pueblos pertenecientes a la Amazonía Legal, la a partir de una encuesta bibliográfica documental. Estos documentos tienen como objetivo dar una mirada al aporte significativo de los pueblos indígenas a la conservación de la biodiversidad, presentando la forma de vida de estos pueblos, el cuidado que tienen con sus territorios para la reproducción física y cultural, así como sus desafíos frente al modelo de desarrollo adoptado a campo traviesa. Las PGTA en cuestión se refieren a los pueblos Jamamadi, Yanomami y Wajãpi, de los respectivos estados de Amazonas, Roraima y Amapá.

PALABRAS-CLAVES: Pueblos indígenas; Amazonia legal; Gestión ambiental y territorial; Políticas públicas. 